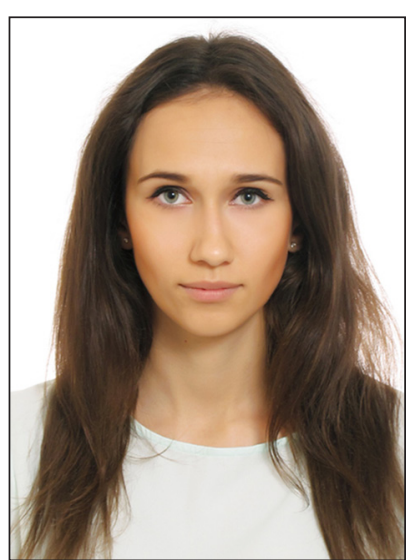

\section{Ельбіс Євгенівна Блошенко,} аспірантка Начіональний юридичний університет імені Ярослава Мудрого, м. Харків

\title{
УАK 349.6:502.211:582
}

\section{РОЗВИТОК НАУКОВО-ПРАВОВИХ АОСАІАЖЕНЬ ВИКОРИСТАННЯ РОСАИННОГО СВІТУ}

Досліджено розвиток наукових досягнень у сфері правового регулювання використання рослинного світу. Проаналізовано сучасний стан вивчення цих відносин на теоретичному рівні.

Ключові слова: екологічне право; рослинний світ; використання рослинного світу.

Актуальність обраної теми зумовлена відсутністю комплексного дослідження правових проблем щодо використання рослинного світу. Тому є потреба у вивченні праць науковців та послідовному їх аналізі. Особливу увагу необхідно приділити роботам тих дослідників, праці яких так чи інакше вплинули на становлення цього правового інституту, а саме використання рослинного світу.

Метою публікації є визначення підстав періодизації наукових досягнень учених задля висвітлення шляху становлення правовідносин у сфері використання рослинного світу, а завданнями - науково-правовий аналіз передумов виникнення та розвитку досліджень у сфері використання рослинного світу, а також сучасний стан вивчення цього питання.

Наукові проблеми щодо регулювання правовідносин приналежності, використання, відтворення та охорони рослинного світу розглядалися в роботах таких правознавців, як: Басай О. В., Гетьман А. П., Горбовий В. Ф., Гиренко I. В., Єлькін С. В., Заславська Л. А., Іскоян А. Б., Колбасов О. С., Краснов Н. І., Крассов О. І., Мельник П. В., Попов В. К., Соколова А. К. та інші.

Правовідносини щодо регулювання рослинного світу стають предметом наукових досліджень лише з кінця 70-х - початку 80-х років XX ст. Хоча у навчальній літературі того часу використання рослинного світу ще не розглядається як окремий об'єкт природоресурсного права поряд з правом зем- 
лекористування, водокористування, надрокористуванням, лісокористуванням, використанням тваринного світу [1, с. 267-270].

Дослідження правовідносин щодо рослинного світу та його елементів різняться; можна виокремити три напрямки вивчення цих відносин. Перша група науковців розглядає окремо лише позалісову рослинність як об'єкт правового регулювання [2; 3]. В інших центром дослідження виступають тільки лісові ресурси [4; 5; 6]. Третя група дослідників розглядає насамперед рослинний світ як сукупність лісової та позалісової рослинності [7; 8; 9; 10; 11]. Ми вважаємо, що необхідно мати на увазі всю рослинність, як лісову, так і ту, яка зростає поза лісом, бо тільки з цієї точки зору можливе комплексне дослідження згідно із діючим українським законодавством, що визначає рослинний світ як сукупність усіх видів рослин, а також грибів та утворених ними угруповань на певній території [12].

На підтвердження слушності цієї точки зору можна навести позицію Краснова Н. I. [13, с. 40]. На його думку, галузева кодифікація законодавства про природокористування не повинна призводити і не призводить до відриву частин елементів єдиної природи. Законодавство про природокористування повинно враховувати властивості і закономірності розвитку не лише суспільства, але й природи. Саме ця особливість не дозволяє розглядати галузі законодавства про природокористування як самостійні і незалежні один від одного, об'єднує їх в єдиний напрям і тим самим відособлює в системі права. Продовжуючи думку, варто зазначити, що єдиним напрямом дослідження правовідносин є галузь флористичного законодавства, яка включає у себе і внутрішню класифікацію.

Першим, хто грунтовно обстоював необхідність правового регулювання відносин з використання рослинного світу, був Колбасов О. С. Він стверджував, що рослинність є важливою складовою частиною навколишнього природного середовища, але їі використання вкрай недостатньо регулюється правом. Лісовим законодавством охоплюється лише та частина рослинності за межами лісів, яка складається з деревних і чагарникових порід. Між тим позалісова рослинність складається не тільки з деревинно-чагарникових насаджень, але й з багатьох видів трав’янистих рослин, що мають для суспільства настільки ж високу цінність, як і ліси [7, с. 71]. Як висновок, Колбасов О. С. наголошував на прийнятті Закону про використання та охорону природної рослинності (позалісової). Цим законом важливо було встановити найбільш загальні й принципові положення з цього питання, зокрема юридично визначити позалісову природну рослинність як об’єкт використання [7; 14].

Основні труднощі при підготовці цього закону пов’язані з тим, що він потребував оптимального поєднання відносин щодо регулювання рослинного світу з лісовими правовідносинами. Для вирішення цього завдання Колбасов О. С. пропонував визнати, що ліси є всього лише частиною рослинного світу, хоча й найбільш вагомою. Далекоглядним було твердження, що історично відокремлене правове регулювання лісових відносин та відносин позалісової природної рослинності втратить таку необхідність. Воно базується, на нашу думку, 
на врахуванні науковцем досягнень природничих наук. У результаті інтеграції правових норм у цій галузі виникне флористичне право як єдність, що охоплює регулювання всіх відносин з використання, охорони і відтворення всієї природної рослинності в країні - як лісової, так і позалісової [7, с. 72].

Серед робіт правознавців слід виділити монографію Горбового В. Ф. «Предмет и система советского лесного права», присвячену дослідженню лісових правовідносин.

Горбовий В. Ф. на противагу деяким науковцям [13, с. 40] вважає найбільш важливими саме суспільні відносини з використання лісів. Розглядаючи лісове право як галузь права, Горбовий В. Ф. виділяє інститут лісокористування, а також його субінститути, а саме: заготівлю деревини, живиці, заготівлю другорядних лісових матеріалів, побічних лісових користувань, користувань лісом у культурно-оздоровчих цілях, у науково-дослідних цілях, користування лісом для потреб мисливського господарства, вільного і загальнодоступного перебування громадян у лісах [4, с. 88-89]. На наш погляд, правовий інститут лісокористування не включає у себе регулювання відносин з використання позалісової рослинності.

Досліджуючи актуальні проблеми охорони навколишнього середовища, Петров В. В. відзначив розгалуженість норм щодо використання рослинного світу і запропонував консолідувати різні джерела на основі Закону про використання та охорону позалісової рослинності [2]. Але цю думку не всі підтримали, наприклад, Заславська Л. А. справедливо критикує консолідацію цих норм i наполягає на їх кодифікації [8, с. 85]. Заславська Л. А. розглянула питання правового регулювання охорони та використання рослинного світу, особливо щодо рослин, які використовуються для харчових, лікарських, кормових цілей, але зростають як у межах державного лісового фонду, так і поза його межами [8, с. 82]. На iï думку, законодавство щодо охорони та використання рослинності, що зростає поза державним лісовим фондом, потребує кодифікації та подальшого розвитку. Науковець пропонує прийняти закон СРСР про охорону та використання рослинного світу, що зростає поза лісами, який поширювався б не тільки на рослини, що зростають на суші, а й на водні рослини [8, с. 84].

У межах цього закону пропонується передбачити правовий режим охорони та використання дикорослих рослин: а) рослин, які використовуються у харчових цілях; б) лікарських рослин; в) рослин, які використовуються для потреб тваринництва (кормових рослин); г) рослин, здобутих в рибогосподарських водоймах; д) рослин, що зростають у континентальному шельфі СРСР [8, с. 86]. Слід наголосити, що ця класифікація є важливою з точки зору врахування можливих напрямків використання рослинного світу для різних господарських цілей.

Дисертаційне дослідження Іскоян А. Б. - це перша праця в радянській правовій науці, у якій комплексно досліджено теоретичні та практичні питання, пов'язані з проблемами удосконалення нормативного регулювання охорони та використання рослинного світу в цілому, і зокрема щодо диких рослин поза лісами [15]. 
Однією з цілей цього дослідження була розробка наукових основ розвитку правового регулювання використання рослинного світу в СРСР, а також підвищення ефективності правового регулювання відносин у цій сфері шляхом консолідації законодавства, приведення його у струнку систему, прийняття Закону СРСР про охорону і використання рослинного світу. Дисертант обгрунтовує єдність правового регулювання відносин з охорони та використання рослинного світу в комплексі правовідносин природокористування та охорони навколишнього середовища. Іскоян А. Б. було сформульовано пропозицію щодо доцільності видання Закону СРСР і законів союзних республік про охорону та використання рослинного світу з акцентом переважно на охорону і регулювання диких рослин поза лісами, а в перспективі видати зведений фундаментальний законодавчий акт стосовно рослинного світу в цілому, включно 3 лісами. А лісокористування взагалі слід розглядати як окремий вид або підвид користування рослинним світом, переконувала авторка [16, с. 19].

Ці пропозиції Іскоян А. Б. були розкритиковані Крассовим О. І., на думку якого співвідношення права лісокористування і права користуванням рослинним світом виражається у співвідношенні однакових за своїм характером видів діяльності стосовно лісової і позалісової рослинності. Наприклад, може йти мова про заготівлю деревини та заготівлі різних видів лікарських і технічних рослин поза лісами, користуванні лісом для науково-дослідних цілей і аналогічної діяльності стосовно позалісової рослинності і т. п. [3, с. 26-27].

На нашу думку, ці положення не є доцільними, бо це призведе до нагромадження правових норм, які регулюють по суті один і той же об’єкт. Тому в даному разі потрібно приводити нормативно-правові акти у впорядковану систему за допомогою такого виду систематизації законодавства, як кодифікація [17, с. 221].

Сучасний етап розпочинається з прийняття у 1999 р. Закону України «Про рослинний світ», який послужив основою для подальших наукових досліджень, у тому числі і щодо правовідносин з використання рослинного світу [12].

Першим, хто зробив грунтовний аналіз цього Закону, був Гетьман А. П. На його думку, Закон України «Про рослинний світ» є першим в Україні (а також на теренах колишнього СРСР) законодавчим актом, що має забезпечити регулювання суспільних відносин у сфері охорони, використання та відтворення об’єктів рослинного світу України. Але не всі питання щодо забезпечення власності, використання, підстав виникнення та припиненням користування рослинним світом тощо урегульовані у цьому Законі [9, с. 109].

Також Гетьман А. П. та Попов В. К. у роботі «Правові проблеми використання і охорони рослинного світу» проаналізували деякі аспекти використання та охорони рослинного світу. Так, рослинний світ поділяється на декілька основних видів, що обумовлено їх природними характеристиками, цільовим використанням та правовим становищем. До основних видів природного рослинного світу, на думку науковців, відносяться: лісові ресурси; рослинність, що не належить до лісових ресурсів; рослинність сільськогосподарського призначення. Найбільш повно урегульовані відносини, які виникають у про- 
цесі використання, відтворення та охорони лісових ресурсів [18, с. 51]. Автори переконані у необхідності подальшої кодифікації законодавства про рослинний світ. На першому етапі пропонується підготувати єдиний Кодекс про рослинний світ, включивши до нього правові норми про лісову та іншу рослинність. А на другому етапі кодифікації екологічного законодавства взагалі доцільно розробити та прийняти Екологічний кодекс України. Правові норми Кодексу про рослинний світ повинні бути включені в Екологічний кодекс і становити його невід'ємну частину [18, с. 53].

Праця Шершуна С. М. (2005р.) містить пропозиції та рекомендації щодо вдосконалення організаційної системи управління у галузі використання та охорони лісів, еколого-правового режиму окремих видів лісокористування, зокрема, щодо систематизації законодавства про рубки у лісах, юридичної відповідальності за лісопорушення [5].

Правовідносини щодо використання рослинного світу так само були предметом дослідження Єлькіна С. В. Автор дійшов висновку, що Закон України «Про рослинний світ» слід розглядати залежно від предмета правового регулювання як загальну правову норму, а лісове законодавство та законодавство про рослинність сільськогосподарського призначення - як спеціальні [19, с. 134].

Басай О. А. в своїй дисертації вказує на неузгодженість між нормами Закону України «Про рослинний світ» та Лісовим кодексом України в частині визначення видів спеціального та загального користування об'єктами рослинного світу. Також, на думку автора, недостатньо повно врегульовано законодавством порядок здійснення спеціального використання природних ресурсів, що не належать до лісової рослинності, нечітко визначено загальні правила щодо обмеження використання природних рослинних ресурсів, залишені поза увагою права та обов'язки користувачів природних ресурсів, гарантії їхніх прав, не визначено строки користування об'єктами рослинного світу, підстави та порядок виникнення і припинення права користування природними рослинними ресурсами [10, с. 52-53].

Фундаментальною й цілісною працею щодо проблем правового регулювання відносин у сфері рослинних ресурсів є монографія Соколової А. К. «Флористичне право України: проблеми формування та розвитку». На думку Соколової А. К., флористичне право характеризується наявністю у ньому групи відокремлених однорідних норм, притаманних двом ㄲï складникам лісовому праву та позалісовому (нелісовому). Авторка пропонує прийняти єдиний нормативно-правовий акт - Флористичний кодекс [11, с. 327]. Одначе вона не заперечує й необхідності у майбутньому прийняти Екологічний кодекс України, у якому знайдуть своє місце і правові норми Флористичного кодексу України.

На нашу думку, така позиція щодо майбутньої кодифікації законодавства в досліджуваній сфері є цілком слушною, і ми підтримуємо пропозицію розглядати відносини щодо використання рослинних ресурсів саме як правовий інститут флористичного права. 
Останнім часом побачили світ ще декілька публікацій з аналізованої нами проблематики [Див.: 20; 21; 22].

Отже, окреслене уможливлює наступні висновки. Правовідносини щодо рослинного світу стали предметом наукових праць лише наприкінці 70-х років $\mathrm{XX}$ ст., хоча ліс як їх основний елемент вивчався ще значно раніше.

Дослідження правовідносин щодо використання рослинного світу варто умовно поділити на два періоди: 1) кінець 70-х років - 1991 р. (проголошення незалежності України); 2) 1999 р. (прийняття Закону «Про рослинний світ») до цього часу.

У роботах радянських правників першого періоду лише окреслено визначення такого об'єкта правового регулювання, як рослинний світ, та досліджено співвідношення його з лісом. Відносини з використання лісових ресурсів вже були закріплені у тогочасних нормативних актах, а проблема використання рослинного світу розроблялась лише на науковому рівні. Тоді ж уперше пропонувалося прийняти Закон про використання та охорону позалісової рослинності [7, с. 71]. Напрацювання вчених першого періоду становлять підгрунтя для розвитку сучасного законодавства.

Другий період - це період розвитку екологічного права незалежної України. Прийняття Конституції України та законів щодо правового регулювання рослинного світу актуалізували наукові дослідження у цій сфері. Українські вчені обгрунтовують необхідність прийняття Флористичного кодексу (Соколова А. К.), Кодексу про рослинний світ (Гетьман А. П., Попов В. К.). Ці кодекси регулюватимуть відносини з лісовикористання, а також використання інших об’єктів позалісової рослинності. Перспективним видається прийняття у майбутньому Екологічного кодексу.

Подальше дослідження й вирішення окреслених правових проблем може бути предметом майбутніх наукових пошуків у межах запропонованої тематики.

Список літератури: 1. Советское природоресурсное право. Часть Особенная : учеб. пособие. - Х. : Вища шк., изд-во при Харьк. ун-те, 1987. - 270 с. 2. Петров В. В. Актуальные проблемы охраны окружающей среды в юридической науке и практике. / В. В. Петров // Проблемы охраны окружающей среды в юридической науке и практике. - М., 1984. 3. Крассов О. И. Право лесопользования в СССР / О. И. Крассов. - М. : Наука, 1990. - 238 с. 4. Горбовой В. Ф. Предмет и система советского лесного права / В. Ф. Горбовой. - Красноярск : Из-во Красноярского ун-та, 1984. - 144 с. 5. Шершун С. М. Еколого-правове регулювання лісокористування в Україні : автореф. дис. на здоб. наук. ступеня канд. юр. наук : спец. 12.00.06 / Шершун С. М. - НАН України ; Ін-т держави і права ім. В. М. Корецького, 2005. - 20 с. 6. Мельник П. В. Правова охорона лісів Карпатського регіону України : автореф. дис. ... канд. юрид. наук / П. В. Мельник. - Х. , 2002. 19 с. 7. Колбасов О. С. Основные направления правотворчества в области охраны окружающей природной среды / О. С. Колбасов // Советское гос-во и право. - 1980. - № 3. - С. 69-77. 8. Заславская Л. А. Правовое регулирование охраны и использования растительного мира / Л. А. Заславская // Советское гос-во и право. - М. : Наука. - 1986. - № 5. - С. 82-86. 9. Гетьман А. П. Проблеми кодифікації законодавства про рослинний світ: деякі міркування (коментар до Закону України «Про рослинний світ») / А. П. Гетьман // Вісник Академії правових наук України. - 1999. - С. 103 - 109. 10. Басай О. В. Правовий режим рослинного світу України : дис. канд. юрид. наук : 12.00 .06 / О. В. Басай. - Івано-Франківськ, 2008. - 214 с. 11. Соколова А. К. 
Теоретичні засади становлення та розвитку флористичного права України : дис. ... д-ра юрид. наук / А. К. Соколова ; конс. М. В. Шульга ; НУ "ЮАУ ім. Ярослава Мудрого". - Х., 2012. 382 с. 12. Про рослинний світ : Закон України від 09.04.1999 р., № 591-XIV // Відом. Верхов. Ради України. - 1999. - № 22-23. - Ст. 198. 13. Краснов Н. И. Новое советское лесное законодательство / Н. И. Краснов // Советское государство и прав. - М. : Наука, 1978. - № 7 - С. 37-45. 14. Колбасов О. С. Соблюдение требований природоохранительного законодательства / О. С. Колбасов // Советское государство и право. - 1986. - № 4. - С. 64 - 71. 15. Искоян А. Б. Проблемы совершенствования правового регулирования охраны и использования растительного мира (диких растений вне лесов) : автореф. дис. ... канд. юрид. наук / А. Б. Искоян. - Ереван, 1985. - 24 с. 16. Искоян А. Б. Охрана растительного мира / А. Б. Искоян. - Ереван, 1985. 30 с. 17. Теорія держави і права : підруч. для студ. юрид. вищ. навч. закл. / О. В. Петришин, С. П. Погребняк, В. С. Смородинський та ін. ; за ред. О. В. Петришина. - Х. : Право, 2014. 368 с. 18. Попов В. К. Правові проблеми використання і охорони рослинного світу / В. Попов, А. Гетьман // Право України. - 2000. - № 1. - С. 51-53. 19. Елькин С. В. История становления правовых основ сохранения и использования растительного мира / С. В. Елькин // Учен. зап. нац. ун-та им. В. И. Вернадского. Серия «Юридические науки». - 2005. - Том 18 (57). № 1. - С. 126-135. 20. Гиренко І. В. Правове регулювання охорони, державного обліку та контролю використання рослинних ресурсів відповідно до Закону України «Про рослинний світ» / I. В. Гиренко // Бюл. Мін-ва юстиції України. - 2013. - № 11. - С. 188-195. 21. Гиренко І. В. Основні етапи оцінки ефективності еколого-правового механізму у сфері охорони та використання рослинного світу / І. В. Гиренко // Підпр-во, госп-во і право : наук.-практ. госп.-прав. журн. - 2013. - № 11. - С. 60-63. 22. Шевердіна І., Шабанов Р. Генеза правового регулювання використання, відтворення та охорони рослинного світу в населених пунктах / І. Шевердина, Р. Шабанов // Вісн. Львів. ун-ту. Серія юридична. - 2013. - № 57. - С. 287-295. 23. Екологічне право : Особлива частина : підруч. для студ. юрид. вузів і фак.: повн. академ. курс / за ред. В. І. Андрейцева ; Київ. нац. ун-т ім. Т. Шевченка. - Київ : Істина. - 2001. - 544 с. 24. Екологічне право : підручник / Нац. ун-т «Юрид. акад. України ім. Я. Мудрого» ; за ред. А. П. Гетьмана. Х. : Право. - 2013. - 432 с. 25. Екологічне право України : Академічний курс : підручник / за заг. ред. Ю. С. Шемшученка. - 2-ге вид. - К. : Юридична думка. - 2008. - 720 с. 26. Екологічне право України : підруч. для студ. вищ. навч. закл. / [Бондар Л. О. та ін.] ; за ред. Каракаша I. I. ; Нац. ун-т "Одес. юрид. акад." - О. : Фенікс. - 2012. - 775 с.

\section{РАЗВИТИЕ НАУЧНО-ПРАВОВЫХ ИССАЕАОВАНИЙ ИСПОАЬЗОВАНИЯ РАСТИТЕАЬНОГО МИРА \\ Блошенко Э. Е.}

Исследовано развитие научных достижений в сфере правового регулирования использования растительного мира. Проанализировано современное состояние изучения этих отношений на теоретическом уровне.

Ключевые слова: экологическое право; растительный мир; использование растительного мира.

\section{DEVELOPMENT OF SCIENTIFIC AND LEGAL STUDIES ON THE USE OF FLORA Bloshenko E. E.}

Development of scientific research studied in the field of legal regulation of plant world usage. The contemporary condition of the study of these relations is analyzed at theoretical level.

Key words: environmental law; world of plants; usage of world of plants.

Надійшла до редколегї 07.10.2014 p. 